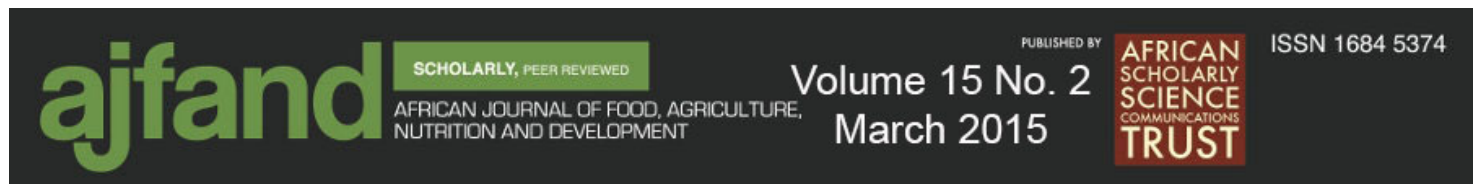

\title{
INFLUENCE BY ARTIFICIAL DEFOLIATION AND NPK FERTILIZER APPLICATION ON GROWTH AND YIELD OF OKRA (Abelmoschus esculentus (L) MOENCH)
}

\section{Nwaoguala $\mathrm{CNC}^{1}$, Law-Ogbomo $\mathrm{KE}^{1^{*}}$ and AU Osaigbovo ${ }^{1}$}

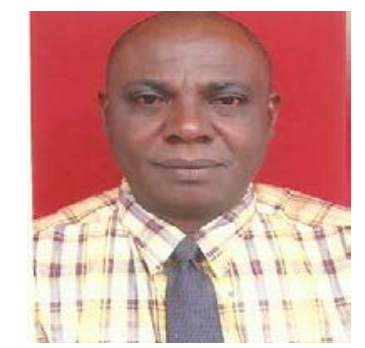

CNC Nwaoguala

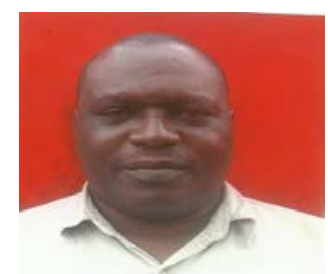

Kola E Law-Ogbomo

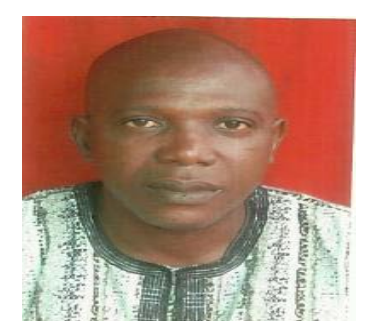

AU Osaigbovo

*Corresponding author email: kolalawogbomo@yahoo.com

${ }^{1}$ Department of Crop Science, Faculty of Agriculture, University of Benin, PMB 1154, Benin City, Nigeria 


\section{ABSTRACT}

A field trial to determine the effect of artificial defoliation and NPK fertilizer application on growth and yield of okra was conducted in 2010 and 2011 at the Teaching and Research Farms of the Faculty of Agriculture, University of Benin, Benin City, Nigeria. Okra "Uselu Local" was sourced locally and subjected to four rates of NPK fertilizer (0, 200 (30 kg N, $13 \mathrm{~kg} P$ and $30 \mathrm{~kg} \mathrm{~K} \mathrm{ha}^{-1}$ ); 400 (60 kg N, $26 \mathrm{~kg} \mathrm{P,} 50 \mathrm{~kg} \mathrm{~K} \mathrm{ha}^{-1}$ ), and 600 (90 kg N, $\left.60 \mathrm{~kg} \mathrm{P,} 90 \mathrm{~kg} \mathrm{~K} \mathrm{ha}^{-1}\right) \mathrm{kg} \mathrm{ha}^{-1}$ ) at different percentages (0, 25 and $50 \%$ ) of defoliation respectively at four and six weeks after sowing. The experiment was laid out as a randomized complete block design arranged in a split-split plot and replicated three times. Each replication was allocated 12 treatments with NPK fertilizer application as the main plot, defoliation (sub-plot) and time of defoliation (sub- sub plot). Data were collected on parameters such as days to $50 \%$ flowering, plant height at which fresh pods were harvested, plant height at which dry pods were harvested, number of pods per stand, average pod weight, pod weight per stand, pod yield per hectare, pod diameter, number of dry pod per stand, number of seeds per pod and stand. Obtained data were analyzed using analysis of variance procedure for split - split plot design and means were compared using LSD at $5 \%$ level of significance. Results obtained indicated that defoliation considerably affected plant height and days to $50 \%$ flowering. The reduction in growth due to defoliation was observed to be significant at four weeks after sowing of okra. NPK fertilizer application significantly reduced the deleterious effects of defoliation with regards to plant heights, days to $50 \%$ flowering and yield of okra. The NPK fertilizer application promoted vegetative growth to cushion the adverse effects of defoliation. The interaction between NPK fertilizer application and defoliation was only significant on number of seeds per pod. There were significant interactive effects between NPK fertilizer and time of defoliation on plant heights and number of seeds per pod. Increasing in NPK fertilizer application above $200 \mathrm{~kg}$ (30 kg N, $13 \mathrm{~kg}$ P and $30 \mathrm{~kg}$ $\mathrm{K} \mathrm{ha}^{-1}$ ) NPK fertilizer ha-1 could be profitable and to bring about a considerable increase in the growth and yield of okra.

Key words: Defoliation, NPK fertilizer, okra, yield 


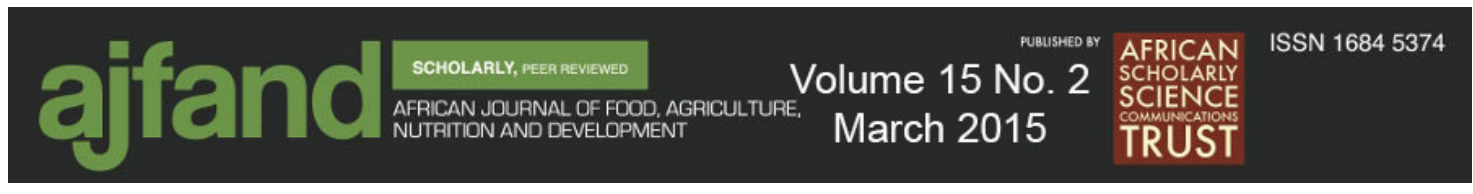

\section{INTRODUCTION}

Okra Abelmoschus esculentus (L) Moench belongs to the family Malvaceae. It is an economically important vegetable crop grown in the tropical and sub-tropical parts of the world. This crop can be cultivated as a garden crop as well as on large commercial farm [1]. Okra is mostly consumed in cooked or processed form. Young fruits may be eaten raw. Its ripe seeds are roasted, ground and used as a substitute for coffee in some countries [2]. In West Africa they are usually boiled in water to make slimy soup and sauces. The fruits can be conserved by drying whole or sliced or by pickling. Young leaves are sometimes used as cattle feed [3]. Okra is also enjoyed in Nigeria where "draw soup” is a popular dish and it is often eaten with garri or fermented cassava [2]. Okra leaves are edible and may be consumed as a potherb; they are sometimes used as a basis for poultices as an emollient or antiscorbutic to treat dysuria while young leaves are sometime consumed as spinach [3]. The usefulness of this crop makes it an important commodity in the local trade and income generation for the farmers.

The crop is cultivated throughout the year in the humid tropical forest zone. However, okra cultivation during the wet season in this location is adversely affected by flea beetles, Podagrical uniformis P. sjostedti [4] and other defoliators. This results from excessive vegetative growth of the plant due to high moisture and coupled with high temperature and relative humidity which favour the growth of the defoliators. These defoliators attack the leaves resulting in extensive leaf perforations and debudding leading to reduction in yield. Reduction in yield was observed to be most severe in the late vegetative and reproduction stages of the plant [4].

Leaves defoliation resulting from human consumption of leaves and also pest defoliators coupled with poor management practices had led to low okra productivity. Average yield per hectare in Nigeria is $2.10 \mathrm{t} \mathrm{ha}^{-1}$, which is very low compared to other countries like India (10.12 t ha-1) and world average (7.65 t ha $\left.{ }^{-1}\right)$ [1]. Optimum crop performance is usually limited by adequate availability of essential nutrients. Fertilizer application is the easiest way of increasing yield per unit. Significant increase in growth and yield of okra has been reported [5].

Adequate fertilizer application can go a long way to ameliorate the effects of leave defoliation. Nitrogen fertilization favours growth and leaf production while phosphorus and potassium improve fruit yield and quality [6]. Hence, the present study is on the effect of artificial defoliation and NPK fertilizer application on the growth and yield of okra.

\section{MATERIALS AND METHODS}

The experiment was conducted at the Teaching and Research Farm, Faculty of Agriculture, University of Benin, Benin City, Edo State, Nigeria. The experiment was conducted between September and December, 2010 and repeated in September to December, 2011 in the humid agro-ecological zone of the country. The location lied within Longitude $5^{0} 4^{\prime}$ East and Latitude $5^{0} 45^{\prime}$ with altitude range of 1000 m.a.s.l. Long term weather data $(1970$ - 2005) at the Nigerian Institute for Oil Palm Research 
(NIFOR), Benin City indicated an annual mean total rainfall of $2000 \mathrm{~mm}$. The rainy season occurs from March to October and maximum rain received in the months of June, July and August. The minimum, maximum and air temperature is $22.5,32$ and $23.6{ }^{\circ} \mathrm{C}$, respectively. The experiment was laid out as a randomized complete block design arranged in a split-split plot and replicated three times with twelve treatments per replication. The size of the experimental site was 24 x $35 \mathrm{~m}$. Each main plot was $7 \times 10$ $\mathrm{m}$ with one metre between blocks. Each replication had 4 main plots and each main plot had three sub plots. Each sub plot had three rows of plants, making a total of 9 rows per plot (main plots). The plants were spaced $50 \times 50 \mathrm{~cm}$ [7]. The main plot treatments were $\mathrm{T}_{0}(0), \mathrm{T}_{1}$ ( 200 (30 kg N, $13 \mathrm{~kg} \mathrm{P}$ and $30 \mathrm{~kg} \mathrm{~K} \mathrm{ha}^{-1}$ ), T2 ( 400 (60 kg N, $26 \mathrm{~kg} \mathrm{P,} 50 \mathrm{~kg}$ $\mathrm{K} \mathrm{ha}^{-1}$ ), and T3 (600 (90 kg N, $60 \mathrm{~kg} \mathrm{P,} 90 \mathrm{~kg} \mathrm{~K} \mathrm{ha}^{-1} \mathrm{~kg}^{-1}$ ) NPK fertilizer kg ha-1). The sub plot treatments were $0 \%$ defoliation (no defoliation), $25 \%$ defoliation and $50 \%$ defoliation. The sub-sub plot treatments were defoliation at 4 and at 6 weeks after sowing (WAS) defoliation.

Soil samples were randomly collected using auger in the experimental site prior to planting at a depth of $0-15 \mathrm{~cm}$. The collected soil samples were bulked together and thoroughly mixed to constitute composite soil sample. The composite soil sample (0 - 15 cm depth) was air dried in laboratory, ground, sieved through a $2 \mathrm{~mm}$ sieve and analyzed for its routine properties using standard laboratory analysis procedure [8]. The seeds were soaked in water for 24 hours and spread on a platform to dry few hours before planting. The non-viable seeds, which remained afloat, were discarded. Three seeds of okra cultivar "Uselu Local" were sown per hole and thinned to one seedling per stand 2 weeks after sowing (WAS).

During defoliation, the leaf blade was severed with a scissors at the point of attachment to the petiole; one-fourth of the leaves were removed (25\% defoliation) and half (50\% defoliation). The site was manually weeded as at three and six WAS. Marshal - Lambda - Cyhalothrin 2.5 Emusifiable Concentrate at $25 \mathrm{ml}$ in 3.5 litres of water was sprayed at 2 weeks interval against insect attack.

Data were collected on days to $50 \%$ flowering, plant heights when fresh pod was harvested (plant height 1 ), fresh pod yield, fresh pod length, pod diameter and number of pods per plant. Plant heights when dry pods were harvested (plant height 2), number of dry pods per plant and number of seeds per pod. The obtained data were combined and subjected to analysis of variance and means were compared using the Least Significant Difference method at 5\% level of significance. The GENSTAT software version 8.1 [9] was used for the statistical analysis.

\section{RESULTS}

Effects of NPK fertilizer application, defoliation and time of defoliation on the growth and yield of okra are presented in Table 2 .

\section{Effects of NPK fertilizer application on the growth and yield of okra}

The tallest plants $(79.23 \mathrm{~cm})$ on which fresh pods were harvested (plant height 1 ) were observed in plants treated with $600 \mathrm{~kg} \mathrm{ha}^{-1}\left(\mathrm{~T}_{3}\right)$ and this was significantly different from 
no fertilizer treatment $\left(\mathrm{T}_{0}\right)$ and plants treated with $200 \mathrm{~kg} \mathrm{NPK}$ fertilizer ha ${ }^{-1}\left(\mathrm{~T}_{1}\right)$ but statically similar with plants treated with $400 \mathrm{~kg}$ ha-1 ( $\left.\mathrm{T}_{2}\right)$. The same trend was observed in plant heights of plants on which dry pods were harvested (plant height 2). However, $\mathrm{T}_{3}$ was taller than $\mathrm{T}_{2}$ while $\mathrm{T}_{0}$ and $\mathrm{T}_{1}$ were statistically comparable. More days to $50 \%$ flowering was observed in fertilizer treated plants than with no fertilizer application. All fertilizer rates were statistically comparable.

In terms of fresh yield components, fertilizer application had significant effect on number of pod per plant and pod yield. The highest number of pod per stand was observed in $\mathrm{T}_{3}$ (16. 72) but was not significantly different from other fertilizer rates except the control which was the least (4.47). Pods yield per plant varied from 61.50 to $257.50 \mathrm{~g}$ for $\mathrm{T}_{0}$ and $\mathrm{T}_{3}$, respectively. However, all fertilizer rates were not significantly different from one another. Fresh pod yield per hectare ranged from 1.28 to $5.37 \mathrm{t} \mathrm{ha}^{-1}$ and followed the trend as pod yield per plant. Fertilizer application had no significant effect on dry pod yield components (number of dry pod per plant, number of seeds per pod and plant).

\section{Effects of defoliation on the growth and yield of okra}

Defoliation decreased plant height 1 at both 25 and $50 \%$ levels. However, at plant height 2 (plant height at which dry pods was produced), significant reduction in height only occurred at $50 \%$ while 0 and $25 \%$ defoliation were not significantly different. Defoliation only adversely affected days to $50 \%$ flowering at $25 \%$ and there was no significant difference between 0 and $50 \%$ defoliation. Defoliation had no significant effect on pod diameter, average pod weight, pod yield per plant and hectare. Defoliation at 25 and $50 \%$ had higher number of fresh pod per plant than no defoliation. However, reverse was the case in pod length.

In terms of dry pod, it ranged from 4.66 to 6.66 pods per plant; number of seeds ranged from 331.10 to 486.50 seeds per plant for 0 and $50 \%$ defoliation, respectively while number of seeds per pod varied from 65.61 and 72.71 seeds for 25 and $50 \%$ defoliation, respectively. In all dry pod components, plants at $50 \%$ defoliation were significantly higher than no defoliation and $25 \%$ defoliation. The control (0\%) and $25 \%$ defoliation were not significantly different.

\section{Effects of time of defoliation on the growth and yield of okra}

Time of defoliation only had significant effects on plant heights. In both cases, taller plants were observed in plots defoliated at six WAS.

\section{Interactions of NPK fertilizer application, defoliation and time of application on the growth and yield of okra}

The interaction effects of NPK fertilizer application and defoliation on number of seeds per pod is presented in fig. 1.The fertilizer and defoliation interactions effect on number of seed per pod was significant and increased as the rate increased for no defoliation to $25 \%$ defoliation. The reverse was the case with $50 \%$ defoliation. The least number of seed per pod was observed in dry pod harvested from plots without fertilizer application and no defoliation (47.30 seeds) while the highest number of seeds was observed from plots defoliated at $50 \%$ without NPK fertilizer treatment (87.6 seeds). 

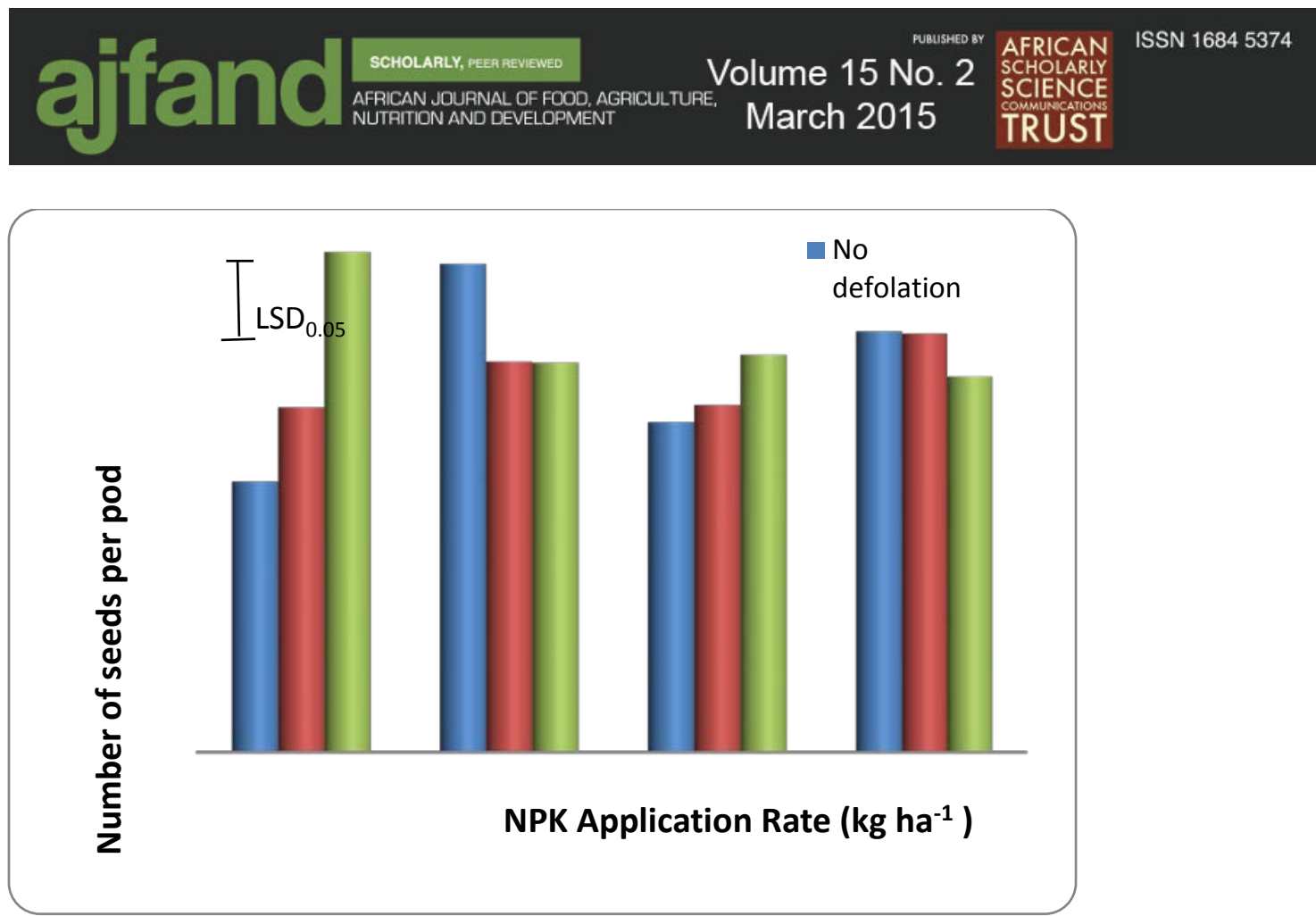

Figure 1: Interaction effects of NPK application and defoliation on number of seeds per pod of okra

Figure 2 shows the interaction effects of NPK fertilizer application and time of defoliation. The interactions effect of NPK fertilizer application and time of defoliation significantly affected plant height. At four and six WAS defoliation, respectively plant height 1 increased with increasing rate of NPK fertilizer application.

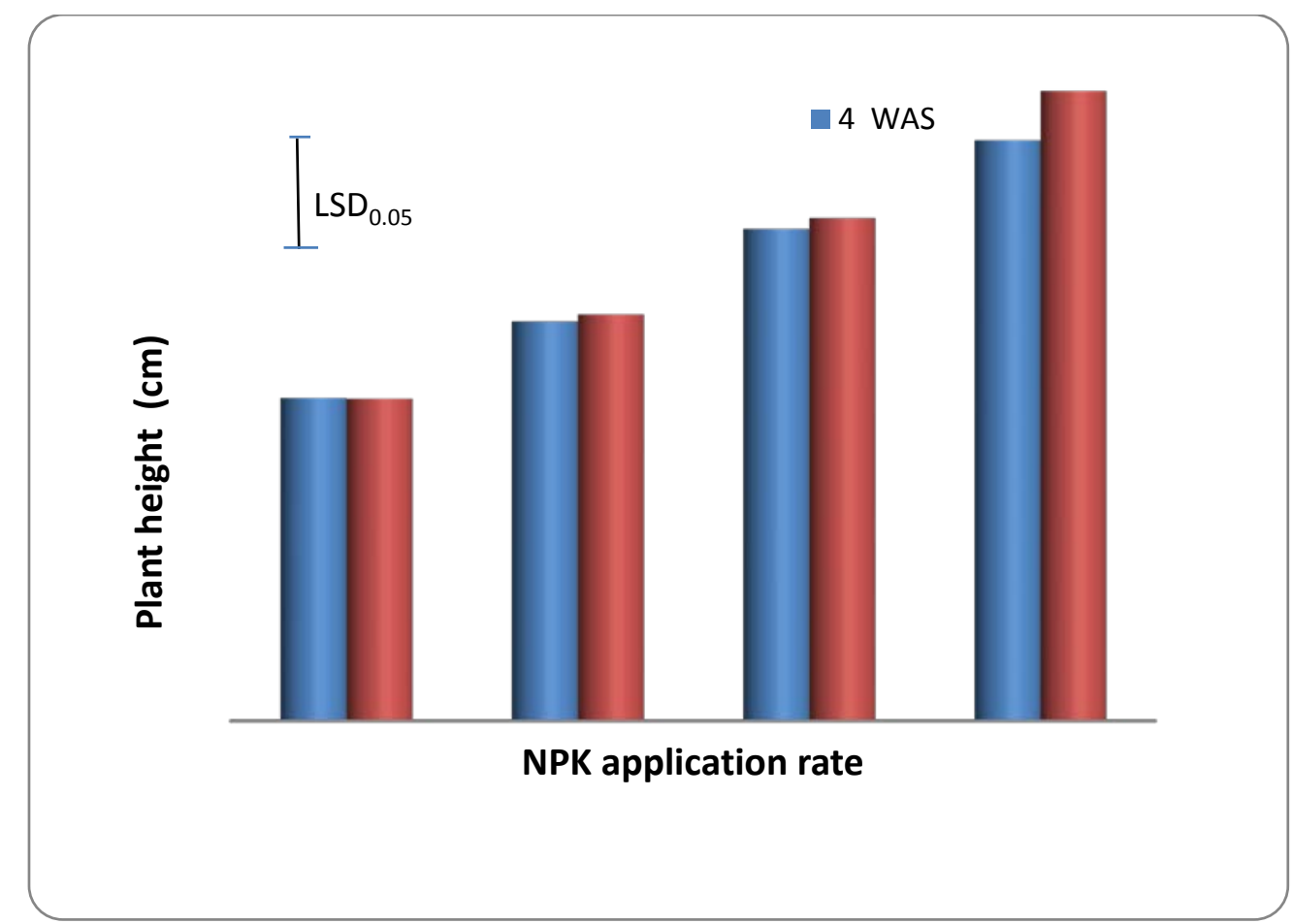

Figure 2: Interaction effects of NPK application and time of defoliation on plant height on which fresh okra pods were harvested 


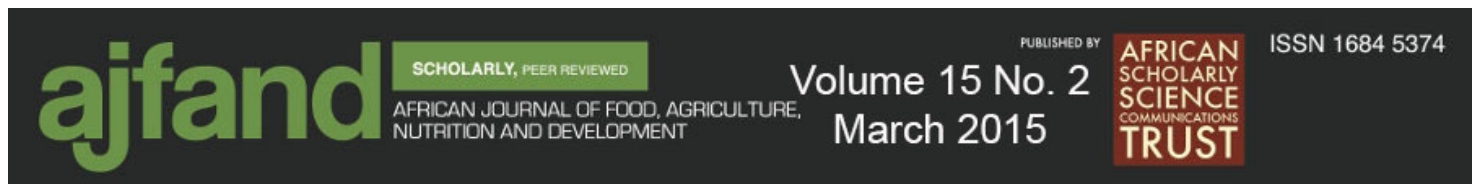

The tallest plants were observed in plots that received $\mathrm{T}_{3}$ and defoliated at six WAS $(82.44 \mathrm{~cm})$. The NPK fertilizer application and time of defoliation interaction effects on plant height 2 differed significantly with NPK fertilizer application rate increasing with time of defoliation (Fig. 3). The highest for plant height 2 was observed from T3 plot defoliated at six WAS $(82.44 \mathrm{~cm})$.

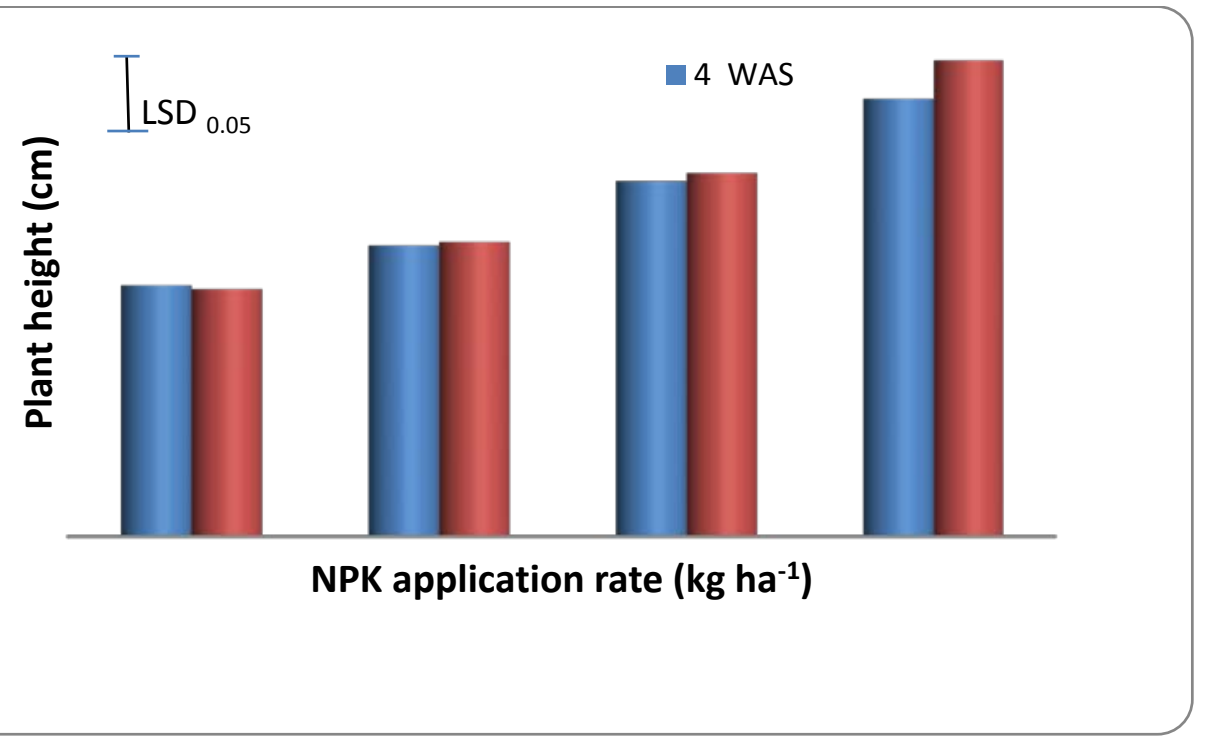

Figure 3: Interaction effects of NPK application and time of defoliation on plant height on plants which dry okra pods were harvested

The NPK fertilizer application and time of defoliation interactions effect significantly affected the number of seeds per pod (Fig. 4). The number of seeds increased with increasing NPK application rate at four WAS defoliation. However, this trend was not maintained at six WAS of defoliation. The highest number of seed per pod (75.40 seeds) was observed in plot with $\mathrm{T}_{1}$ defoliated at six WAS.

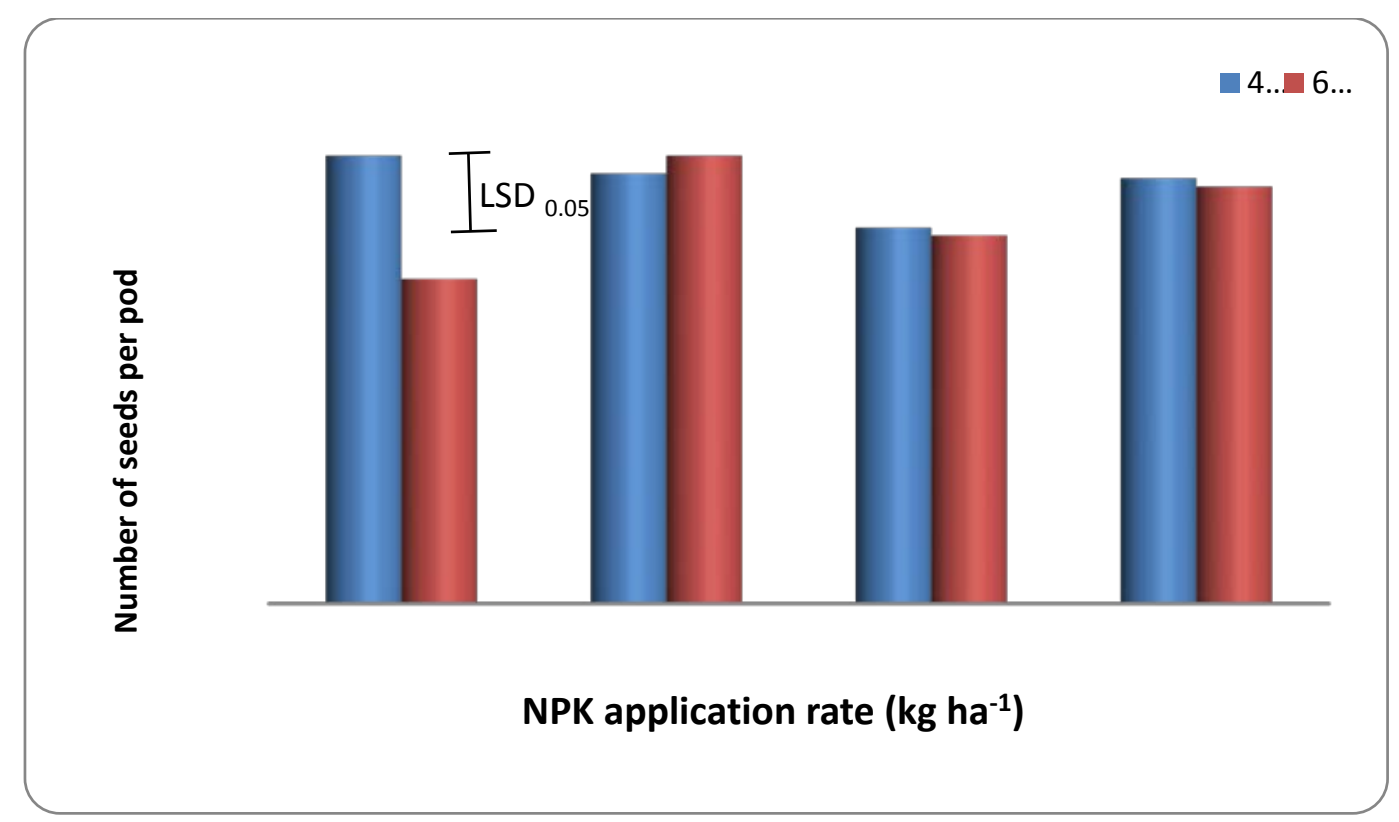

Figure 4: Interaction effects of NPK application and number of seeds per okra pod 


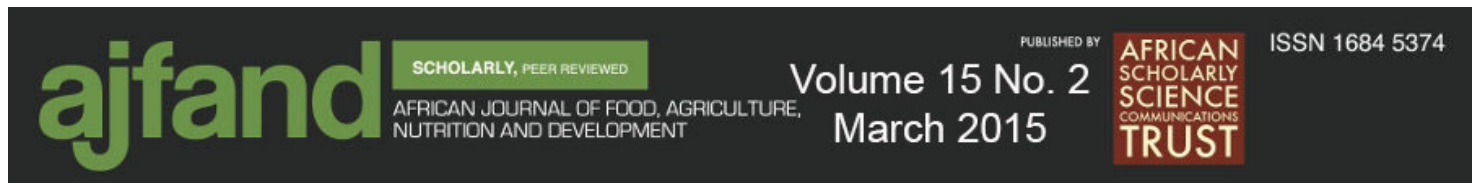

\section{DISCUSSION}

The essence of crop improvement and management practices is for higher yield. This study showed that NPK fertilizer application enhanced growth and fresh pod yield in okra. This, therefore, emphasizes the usefulness of fertilizer in improving plant productivity. The fertilizer contains $\mathrm{N}, \mathrm{P}, \mathrm{k}$ and micronutrients that can be used directly by the plants. The applied NPK fertilizer contain $\mathrm{N}$ which promotes the vegetative growth of the plant. P plays an important role in growth and development of the plant. It enhances photosynthesis and energy/nutrient transport. P also encourages blooming and root growth. $\mathrm{k}$ strengthens straw, increase disease resistance and help the plant better withstand stress.

More days to $50 \%$ flowering was observed in fertilizer treated plants. This could probably attribute to an extended vegetative growth phase resulting in delay in flowering and fruiting. This delay does not depressed yield instead, it led to increased fresh pod yield. Yield was significantly reduced in plots without fertilizer treatment [5]. This has arisen because plants had to rely on the soil native fertility which, from the results of chemical analysis was moderate in these nutrients except in total $\mathrm{N}$ which was found to be deficient.

Leaf is the main vegetative part of the plant supplying assimilates to developing organs and a measure of its productivity. The leaf lamina possesses chlorophyll which constitute principal site of photosynthetic activity [10]. The chlorophyll in the leaves fix carbon into carbon compounds which are consequently converted to organic compounds (proteins, carbohydrates and lipids). Assimilates produced by the leaves depend on the leaf area index which is an indicator of photosynthetic capacity and translocation [11].

Defoliation in okra through leaf eating insects, disease infestation, man and other environmental factors has resulted in remarkable yield loss and reduced market value due to reduction in source sizes and total sink production. This study has re-emphasized that defoliation of okra impaired plant growth [4]. Presumably less assimilates are produced and distributed to organs of the plants that have been defoliated especially the root systems which is the site of protein synthesis. The shortage of assimilates in the root system may have resulted in poor growth and consequently affected the uptake and distribution of nutrients [12]. This interplay of factors possibly resulted in slow growth rate of defoliated plants and delay in flowering. Similarly observation has been reported in maize. Maize grain yield was reduced by defoliation resulting from ear sizes that were also poorly filled [13]. It was also observed that number and weight of kernel were adversely affected by leaf removal leading to the failure of kernels to develop near the tip end of the ear.

In this this study, defoliation was more harmful on plants at early stage of vegetative growth than at advanced stage. This could probably be attributed to the fact that at four WAS, the remaining leaves of defoliated plants had lower photosynthetic capacity than plant at six WAS due to leaf sizes. This emphasized that defoliation during flowering stage had less adverse effect on the yield because defoliated leaves had aged, photo- 


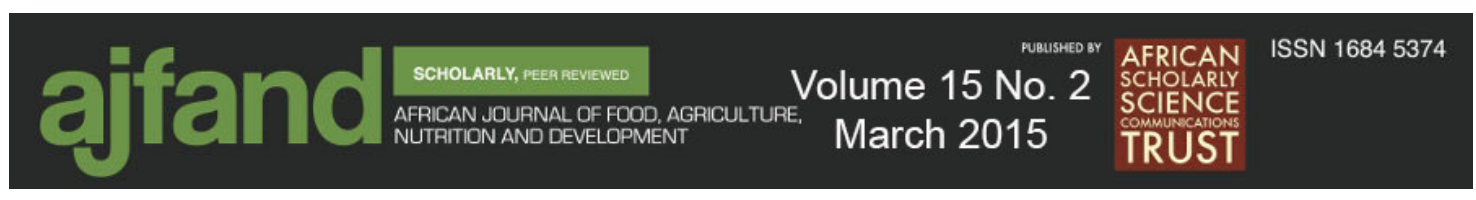

synthetically less active and may act as burden and compete for assimilate with growing pods. However, most of assimilates translocated to the pods when fewer leaves are present could lead to increase in number of seeds per pod.

In this study, NPK fertilizer application was an effective compensatory mechanism that enhanced the regrowth of leaves in defoliated plants and significantly reduced the harmful effect of defoliation on plants. This had probably resulted in production of assimilates through increased source size capacity and promoted the vegetative growth of the defoliated okra plants.

\section{CONCLUSION}

It is, therefore, recommended that under prevailing conditions (soil nutrient status, weather, pest and diseases infestation) increase in NPK fertilizer application above 200 (30 kg N, $13 \mathrm{~kg} \mathrm{P}$ and $30 \mathrm{~kg} \mathrm{~K} \mathrm{ha}^{-1}$ ) NPK fertilizer $\mathrm{kg} \mathrm{ha}^{-1}$ could be profitable to cushion the effect of defoliation and bring about a considerable increase in the growth and yield components of okra. More so, it is plausible profitable to prevent leaf perforations at the initial stages of okra development as this would determine to a great extent the harvestable components of the okra plants. 


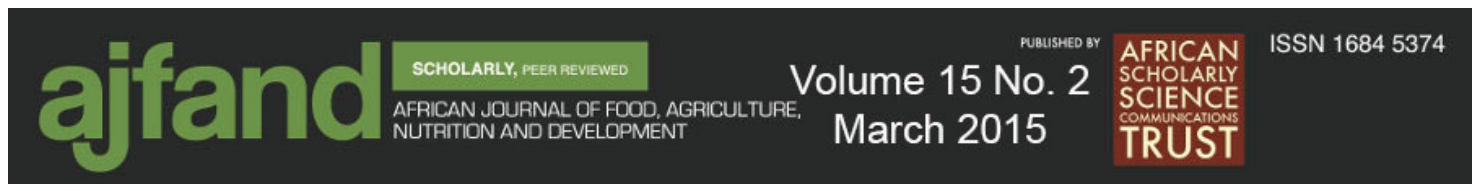

Table 1: Physical and chemical properties of the soil at the experimental site

\begin{tabular}{lc}
\hline Parameter & Value \\
\hline Sand $\left(\mathrm{g} \mathrm{kg}^{-1}\right)$ & 8.50 \\
$\mathrm{Silt}\left(\mathrm{g} \mathrm{kg}^{-1}\right)$ & 30.00 \\
Clay $\left(\mathrm{g} \mathrm{kg}^{-1}\right)$ & 120.00 \\
$\mathrm{pH}\left(\mathrm{H}_{2} \mathrm{O}\right)$ & 4.55 \\
Organic carbon $\left(\mathrm{g} \mathrm{kg}^{-1}\right)$ & 1.64 \\
Total nitrogen $\left(\mathrm{g} \mathrm{kg}^{-1}\right)$ & 0.96 \\
Available Phosphorus $\left(\mathrm{mg} \mathrm{kg}^{-1}\right)$ & 8.85 \\
Exchangeable cations $(\mathrm{c} \mathrm{mol} \mathrm{kg})$ & \\
Calcium & 1.00 \\
Potassium & 0.40 \\
Magnesium & 0.34 \\
\hline
\end{tabular}




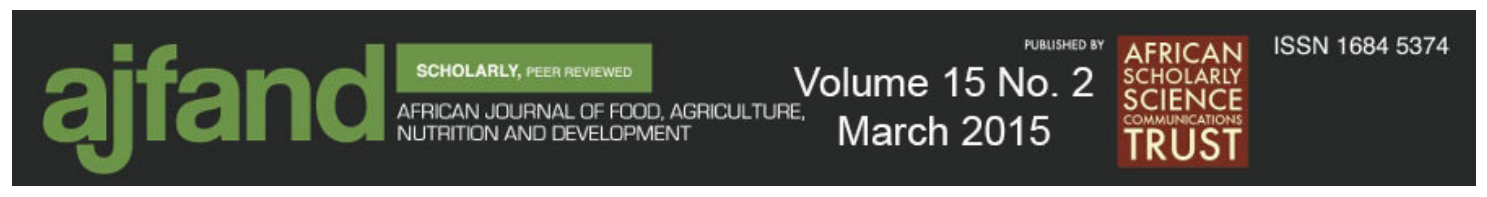

Table 2: The effect of NPK fertilizer application, defoliation and time of defoliation on growth and yield components of okra

\begin{tabular}{|c|c|c|c|c|c|c|c|c|c|c|c|c|c|}
\hline \multirow{2}{*}{\multicolumn{2}{|c|}{ Treatment }} & \multirow{2}{*}{$\begin{array}{c}\text { Plant height } 1 \\
(\mathrm{~cm})\end{array}$} & \multirow{2}{*}{$\begin{array}{c}\text { Plant height } 2 \\
\text { (cm) }\end{array}$} & \multirow{2}{*}{$\begin{array}{l}\text { Days to } 50 \% \\
\text { flowering }\end{array}$} & \multirow{2}{*}{$\begin{array}{c}\text { Nos. of pod } \\
\text { (stand }^{-1} \text { ) }\end{array}$} & \multirow{2}{*}{$\begin{array}{c}\text { Pod length } \\
(\mathrm{cm})\end{array}$} & \multirow{2}{*}{$\begin{array}{c}\text { Pod diameter } \\
(\mathrm{cm})\end{array}$} & \multirow{2}{*}{$\begin{array}{l}\text { Average pod } \\
\text { weight (g) }\end{array}$} & \multirow{2}{*}{$\begin{array}{l}\text { Pod weight } \\
\text { (g stand }^{-1} \text { ) }\end{array}$} & \multirow{2}{*}{$\begin{array}{c}\text { Pod yield } \\
\left(\mathrm{t} \mathrm{ha}^{-1}\right)\end{array}$} & \multirow{2}{*}{$\begin{array}{c}\text { Nos. of dry pod } \\
\quad\left(\text { stand }^{-1}\right)\end{array}$} & \multicolumn{2}{|c|}{ Nos. of seeds } \\
\hline & & & & & & & & & & & & $\left(\right.$ pod- $\left.^{-1}\right)$ & $\left(\operatorname{stand}^{-1}\right)$ \\
\hline \multicolumn{14}{|c|}{ NPK $\left(\mathrm{kg} \mathrm{ha}^{-1}\right)$} \\
\hline 0 & $\left(\mathrm{~T}_{0}\right)$ & 43.37 & 44.44 & 35.63 & 4.47 & 8.14 & 6.19 & 14.02 & 61.50 & 1.28 & 3.61 & 257.60 & 65.04 \\
\hline & $\left(\mathrm{T}_{1}\right)$ & 52.78 & 51.94 & 55.25 & 13.00 & 7.89 & 6.24 & 14.16 & 188.00 & 3.92 & 5.75 & 432.30 & 73.92 \\
\hline & $\left(T_{2}\right)$ & 65.13 & 63.77 & 60.33 & 11.72 & 8.04 & 6.21 & 14.07 & 158.70 & 3.31 & 4.86 & 314.60 & 62.64 \\
\hline & $\left(\mathrm{T}_{3}\right)$ & 79.23 & 81.06 & 63.67 & 16.72 & 8.25 & 6.34 & 15.13 & 257.50 & 5.37 & 7.46 & 528.00 & 70.87 \\
\hline LSD & & 15.27 & 13.64 & 8.960 & 8.450 & ns & ns & Ns & 140.30 & 2.920 & ns & ns & ns \\
\hline \multicolumn{14}{|c|}{ Defoliation (\%) } \\
\hline 0 & & 64.20 & 63.66 & 55.00 & 9.71 & 8.48 & 6.41 & 15.36 & 155.90 & 3.25 & 4.66 & 331.10 & 66.03 \\
\hline 25 & & 59.24 & 61.11 & 51.65 & 11.37 & 7.88 & 6.10 & 13.11 & 148.90 & 3.10 & 4.94 & 331.80 & 65.61 \\
\hline 50 & & 56.18 & 55.50 & 54.50 & 13.36 & 7.89 & 6.22 & 14.56 & 144.50 & 4.05 & 6.66 & 486.50 & 72.71 \\
\hline LSD & & 4.040 & 2.980 & 2.560 & 3.190 & 0.480 & ns & Ns & Ns & $\mathrm{ns}$ & 1.190 & 83.000 & 6.050 \\
\hline \multicolumn{14}{|c|}{ Time of defoliation } \\
\hline $4 \mathrm{WA}$ & & 58.79 & 59.22 & 60.31 & 12.43 & 8.07 & 6.23 & 13.48 & 168.90 & 3.52 & 5.92 & 426.00 & 70.70 \\
\hline $6 \mathrm{~W}$ & & 60.96 & 61.28 & 61.04 & 10.53 & 8.09 & 6.26 & 15.21 & 164.00 & 3.42 & 4.92 & 340.00 & 65.60 \\
\hline LSD & & 1.300 & 1.560 & ns & ns & ns & ns & Ns & Ns & ns & ns & ns & ns \\
\hline \multicolumn{14}{|c|}{ Interactions } \\
\hline LSD & NPK $x$ defoliation & ns & ns & ns & ns & ns & ns & Ns & Ns & ns & ns & ns & 15.290 \\
\hline LSD & NPK $x$ time of defoliation & 15.283 & 13.607 & ns & ns & ns & ns & Ns & Ns & ns & ns & ns & 14.560 \\
\hline $\begin{array}{l}\text { LSD } \\
\text { LSD }\end{array}$ & $\begin{array}{l}\text { Defoliation x time of defoliation } \\
\text { NPK x defoliation } x \text { time of }\end{array}$ & ns & ns & ns & ns & ns & ns & Ns & Ns & ns & ns & ns & ns \\
\hline defol & & ns & ns & ns & ns & ns & ns & Ns & Ns & ns & ns & ns & ns \\
\hline
\end{tabular}

ns - not significant 


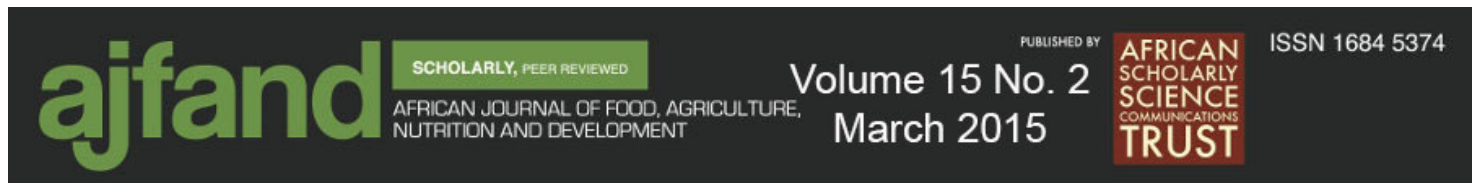

\section{REFERENCES}

1. FAOSTAT. Food and Agriculture Organization of the United Nations. FAO Statistics Division 2012.

2. Raemakers RH Crop Production in Tropical Africa. CIP Royal Library Albert I, Brussels, Belgium 2001; 1450 pp.

3. Siemonsma JS and C Kouame Abelmoschus esculentus (L) Moench In: Grubben, GJH and Denton OA (eds.). Plant resources of tropical Africa 2. Vegetables PRDATAFoundation,Wageningen, Bachuys Publisher, Leiden, Netherlands, CTA, Wageningen, Netherlands, 2004; 25 - 29.

4. Iremirem GO Effects of artificial defoliation on the growth and yield of okra (Abelmoschus esculentus (L.) Moench). Experimental Agriculture 1988; 23: 1 9.

5. Omotoso SO and OS Shittu Effect of NPK Fertilizer rates method of application in growth and yield of Okra (Abelmoschus esculensus (L) moench) at Ado-Ekiti, South Western Nigeria. International Journal of Agricultural Research 2007; 2: $614-619$.

6. Schippers RR African Indigenous Vegetables - an overview of the cultivated species, National Resource Institute (NRI), University of Greenwich, London, United Kingdom 2000; 214 pp.

7. Akintoye HA, Adebayo AG and OO Aina Growth and yield response of okra intercropped with live mulches. Asian Journal of Agricultural Research 2011; $146-153$.

8 Mylavarapus RS and D Kennelley UF//IFAS extension soil testing laboratory (ESTL): Analytical procedures and training manual. Institute of Food and Agricultural Science, University of Florida, Gainsville, USA, 2002; 28 pp.

9. GENSTAT. Gentstat Release 8.1. Statistical Software. VSN International Ltd, Rothamsted, U 2005.

10. Ogoke IJ, Egesi CN and JC Obiefuna A review of some non-destructive linear measurement procedures for leaf area determination in crops. International Journal of Agriculture and Rural Development 2003; 4: 74 - 80.

11. Law-Ogbomo KE and SU Remison The response of Dioscorea rotundata to NPK fertilizer in Edo State, Nigeria. Research Journal of Agriculture and Biological Sciences, 2007; 3: 917-923. 
12. Gulshan M, Sharda R, Kumar A and KG Singh Effect of plastic mulch on economizing irrigation water and weed control in baby corn sown by different methods. African Journal of Agricultural Research 2004; 2(1): 19-26.

13. Egharevba PN, Horrocks R D and MS Zuber Dry matter accumulation of maize in response to defoliation. Agronomy Journal 1976; 68:40-43. 